\title{
Effect of irradiation mode and filling technique on resin/dentin bonding strength in class I cavities
}

\section{Efeito do modo de ativação e da técnica restauradora na resistência de união entre compósito e dentina em cavidades classe I}

\author{
Alex José Souza dos Santos* \\ Marcelo Giannini** \\ Luis Alexandre Maffei Sartini Paulillo*** \\ José Roberto Lovadino**** \\ Ricardo Marins de Carvalho*****
}

\begin{abstract}
Factors such as light-curing mode, filling technique and cavity configuration may affect the bonding strength to dentin. This study evaluated the effect of irradiation mode and filling technique on resin/dentin bonding strength on the buccal wall of class I cavities in human teeth. Occlusal enamel was removed to expose a flat dentin surface. Occlusal cavities $(4 \times 3 \times 3 \mathrm{~mm})$ were prepared in dentin. The adhesive Single Bond was applied according to the manufacturer's instructions and TPH Spectrum composite resin was placed using the following: oblique incremental, horizontal incremental or bulk filling techniques. The composite resin was light-cured either by continuous $\left(600 \mathrm{~mW} / \mathrm{cm}^{2}\right.$ for $\left.40 \mathrm{~s}\right)$ or Soft-Start $\left(250 \mathrm{~mW} / \mathrm{cm}^{2}\right.$ for $10 \mathrm{~s}+600 \mathrm{~mW} / \mathrm{cm}^{2}$ for $\left.30 \mathrm{~s}\right) \mathrm{modes}$. Specimens of the control group were obtained by bonding the material to the flat exposed buccal wall of the cavity $(\mathrm{C}$-factor $=1)$. The teeth were stored in water at $37^{\circ} \mathrm{C}$ for $24 \mathrm{~h}$ and prepared for microtensile testing. Bonded beams of approximately $0.8 \mathrm{~mm}^{2}$ were obtained from the buccal wall and tested with a tension of $0.5 \mathrm{~mm} / \mathrm{min}$. Results were analyzed by two-way ANOVA, Tukey's test and Dunnett's test $(\alpha=0.05)$. Incremental placement techniques with both irradiation modes produced higher bonding strength values than the bulk technique $(\mathrm{p}<0.05)$. Bonding strength tested in the cavities had lower values than those obtained in flat dentin surfaces (control group) $(p<0.05)$, except for incremental fillings using stepped irradiation. Bonding strength to the cavity walls depends on the filling technique and on the irradiation mode of composite resins.
\end{abstract}

DESCRIPTORS: Composite resins; Dentin; Dental cements; Dental enamel.

\begin{abstract}
RESUMO: Fatores como o modo de ativação, a técnica restauradora e a configuração cavitária podem afetar a resistência adesiva à dentina. Este estudo avaliou os efeitos dos modos de ativação e das técnicas restauradoras na resistência de união compósito/dentina na parede vestibular de restaurações classe I. O esmalte oclusal dos dentes foi removido para expor uma superficie dentinária planificada. Cavidades oclusais ( 4 × 3 x $3 \mathrm{~mm}$ ) foram preparadas em dentina. O adesivo Single Bond foi aplicado de acordo com as instruções do fabricante, e o compósito TPH Spectrum, inserido através de três diferentes técnicas: obliqua incremental, horizontal incremental ou incremento único. O compósito foi ativado utilizando o método contínuo $\left(600 \mathrm{~mW} / \mathrm{cm}^{2}\right.$ por $\left.40 \mathrm{~s}\right)$ ou "Soft-Start" $\left(250 \mathrm{~mW} / \mathrm{cm}^{2}\right.$ por $10 \mathrm{~s}+600 \mathrm{~mW} / \mathrm{cm}^{2}$ por $\left.30 \mathrm{~s}\right)$. O grupo controle foi obtido pela união somente à parede vestibular planificada (fator $\mathrm{C}=1$ ). Os dentes foram armazenados por $24 \mathrm{~h}$ em água a $37^{\circ} \mathrm{C}$ e preparados para o ensaio de microtração $(0,5 \mathrm{~mm} / \mathrm{min})$. Os espécimes apresentaram na secção transversal uma área de união de aproximadamente $0,8 \mathrm{~mm}^{2}$. Os resultados foram analisados pela ANOVA (dois fatores), pelos testes de Tukey e Dunnett $(\alpha=0,05)$. A técnica incremental seguida da ativação com ambas as formas de fotopolimerização produziu maiores valores de resistência de união que a técnica de incremento único $(\mathrm{p}<0,05)$. A resistência de união sempre foi menor quando a restauração foi confeccionada em cavidade $(p<0,05)$, exceto quando foram utilizadas ativação com "Soft-Start" e técnicas incrementais. A resistência de união às paredes cavitárias é dependente da técnica de inserção e do modo de ativação da resina composta.
\end{abstract}

DESCRITORES: Resinas compostas; Dentina; Cimentos dentários; Esmalte dentário.

${ }^{*}$ PhD Student; **Assistant Professor; ${ }^{* * *}$ Associate Professor ${ }^{* * * *}$ Chairman, Professor - Department of Restorative Dentistry, School of Dentistry of Piracicaba, State University of Campinas.

$* * * * *$ Associate Professor, Department of Operative Dentistry, Endodontics and Dental Materials, School of Dentistry of Bauru, University of São Paulo. 
Santos AJS, Giannini M, Paulillo LAMS, Lovadino JR, Carvalho RM. Effect of irradiation mode and filling technique on resin/dentin bonding strength in class I cavities. Braz Oral Res 2004;18(3):260-5.

\section{INTRODUCTION}

Composite resins have been widely used in restorative and esthetic dentistry as direct restorative materials. However, the restorative technique in three-dimensional cavities consists of sensitive steps such as adhesive application, composite insertion and photo-activation techniques ${ }^{2,18}$.

Despite recent development in resin-based restorative materials, the amount of shrinkage reported still poses a clinically relevant problem. The monomers used in restorative dentistry are methacrylate- or acrylate-based, and they undergo shrinkage during polymerization. If the stress resulting from composite shrinkage exceeds the bonding strength to the cavity wall, marginal failures can occur due to disruption of the compositetooth adhesive interface ${ }^{4,7,19}$. If bonded interfaces remain intact, residual forces might transfer stress to adjacent tooth structures, possibly resulting in enamel fractures ${ }^{9,23}$.

Bonding failure is a common cause of replacement of composite resin restorations. Studies have reported that high values of contraction stress for specific configurations of cavity preparation can affect the integrity of the restoration-cavity interface. This might explain the large number of early bond failures ${ }^{4,6,15}$. Different filling and photo-activation techniques have been developed in an attempt to reduce the shrinkage potential and produce minimal interfacial stress development ${ }^{2,18}$.

Soft-start polymerization or stepped light intensity uses an initial low-output intensity of light followed by a higher intensity of light ${ }^{13,22}$, and incremental insertion of composite resin reduces the volume of the restorative material that shrinks under photo-activation ${ }^{8,12,17}$. Both methods have been advocated because they minimize stress generated during polymerization and improve the marginal sealing and cavity wall adaptation of restorations ${ }^{18}$. The purpose of this study was to evaluate the influence of two irradiation modes and three filling techniques on the tensile bond strength of a composite resin to the dentin of the buccal wall of box-like class I cavities, using the microtensile bond test. The null hypothesis tested was that irradiation modes and filling techniques do not affect the tensile bonding strength.

\section{MATERIALS AND METHODS Cavity preparation}

Thirty-two sound human third molars that had been refrigerated in a solution of $0.05 \%$ thymol
(LabSynth, Diadema, Brazil) for no longer than two months after extraction were cleaned of gross debris and placed in distilled water for twenty-four hours before beginning the experiment. The teeth used in this study were obtained under the protocol 039/2002, which was analyzed and approved by the Ethical Committee in Research, School of Dentistry of Piracicaba, State University of Campinas.

The occlusal enamel was removed using a diamond saw (Isomet, Buehler Ltd., Lake Bluff, USA), under water-cooling, to expose superficial dentin parallel to the occlusal surface (Figure 1A). Standardized uniform box-shaped class I cavities were prepared with a precision cavity preparation device on flat occlusal surfaces of twenty-four teeth. The preparations were outlined with diamond burs (\#2143 - KG Sorensen Ind. e Com. Ltda., Barueri, Brazil) using a high-speed handpiece (Extra-Torque 605, Kavo do Brasil S.A., Joinville, Brazil) and copious air-water spray (Figure 1B). The buccolingual width of the preparations was $4 \mathrm{~mm}$, the mesio-distal width was $3 \mathrm{~mm}$ and the pulpal floor was prepared to a depth of $3 \mathrm{~mm}$ (Figure 1C).

Eight teeth from the control group (corresponding to flat buccal dentin surfaces) were prepared the same way, but cavities were enlarged after preparation (Figure 1D). The cavity preparation device was adjusted to remove all surrounding dental structures, leaving a flat buccal dentin area ( $3 \mathrm{~mm} \times 4 \mathrm{~mm}$ ) with the same texture for the bonding procedures.

\section{Restorative procedures}

Single Bond (3M/ESPE, St. Paul, USA) was applied according to the manufacturer's instructions and TPH Spectrum composite resin (Dentsply Caulk, Milford, USA) was placed either using oblique incremental, horizontal incremental or bulk filling techniques. For the oblique incremental technique, the composite resin was applied to the cavity and cured in three oblique increments, as suggested by Pollack ${ }^{17}$ (1987) in class II cavities. Each layer was light cured for $40 \mathrm{~s}$ from the occlusal surface.

For the horizontal incremental technique, two increments $1.5 \mathrm{~mm}$ thick were applied and each layer was photo-activated for $40 \mathrm{~s}$ from the occlusal surface. For the bulk filling technique, the composite was occlusally photo-cured for $40 \mathrm{~s}$. Composite resin blocks ( $3 \mathrm{~mm}$ high) were built in two increments on the flat buccal dentin surfaces 
Santos AJS, Giannini M, Paulillo LAMS, Lovadino JR, Carvalho RM. Effect of irradiation mode and filling technique on resin/dentin bonding strength in class I cavities. Braz Oral Res 2004;18(3):260-5.

of the control group and cured for 40 seconds (each layer).

The restorative composite resin was lightcured (Degulux Soft-Start, Degussa, Hanau, Germany) either by continuous $\left(600 \mathrm{~mW} / \mathrm{cm}^{2}\right.$ for $\left.40 \mathrm{~s}\right)$ or stepped $\left(250 \mathrm{~mW} / \mathrm{cm}^{2}\right.$ for $10 \mathrm{~s}+600 \mathrm{~mW} / \mathrm{cm}^{2}$ for $30 \mathrm{~s}$ ) irradiation modes. The intensity of $250 \mathrm{~mW} / \mathrm{cm}^{2}$ was obtained with the light tip $13 \mathrm{~mm}$ distant from the resin, and the $600 \mathrm{~mW} /$ $\mathrm{cm}^{2}$ intensity with the tip touching the restorative material. The light intensity was measured using a radiometer (Demetron Corp., Danbury, USA).

\section{Micro-tensile testing}

After $24 \mathrm{~h}$ of storage in water at $37^{\circ} \mathrm{C}$, the restored specimens were buccal-lingually and mesio-distally serially sectioned (Figure 2A and 2B) with a saw (Isomet, Buehler Ltd., Lake Bluff, USA) resulting in bonded beams with a cross-sectional area of approximately $0.8 \mathrm{~mm}^{2}$ (Figure 2C). Three or four specimens were selected from each restored teeth and tested in a universal testing machine (4411, Instron Co., Canton, USA) at $0.5 \mathrm{~mm} / \mathrm{min}$ until failure in the bonding system occurred (Figure 2D).

The cross-sectional area for each tested specimen was measured to the nearest $0.01 \mathrm{~mm}$ with a digital caliper (727-6/150, Starret, Itu, Brazil) to calculate the tensile bond strength and express results in $\mathrm{MPa}$. Results were analyzed by two-way ANOVA (irradiation mode and filling technique), Tukey's test and Dunnett's test at the 0.05 level of significance. All statistical analyses were performed using SAS for personal computers (SAS Institute, Cary, NC, USA).

\section{RESULTS}

Two-way ANOVA (Table 1) indicated that there were statistically significant differences for the variables filling technique $(\mathrm{p}=0.0002)$ and irradiation mode $(\mathrm{p}=0.0034)$, but failed to identify any interaction between variables $(\mathrm{F}=1.91 ; \mathrm{p}=0.1766)$.

The mean tensile bonding strength and standard deviation values are shown in Table 2 . Tukey's test showed that the bulk filling technique presented significantly lower bonding strength values than the incremental filling techniques (horizontal and oblique), using both irradiation modes $(p<0.05)$. The photo-activation with stepped light intensity resulted in significantly higher bonding strength values than the conventional continuous irradiation for all filling techniques, except for control groups $(\mathrm{p}<0.05)$.

Dunnett's test indicated that the bonding strength values of composite restorations incre-

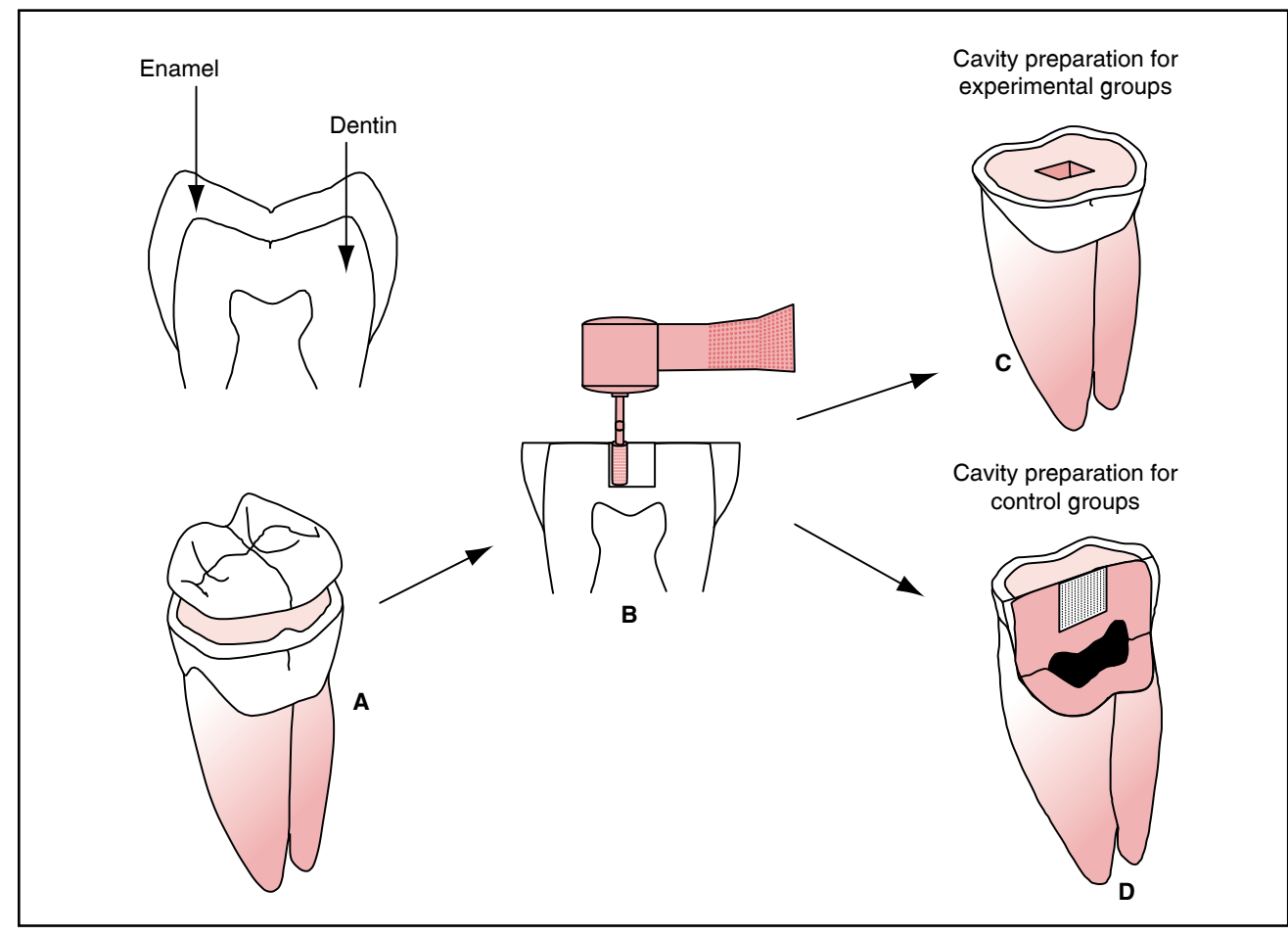

FIGURE 1 - Schematic representation of cavity preparation. (A) Removal of occlusal enamel; (B) cavity preparation using a diamond bur and a high-speed handpiece; (C) prepared class I cavity for bulk or incremental fillings; (D) control group cavity design with a flat buccal dentin surface for bonding. 
Santos AJS, Giannini M, Paulillo LAMS, Lovadino JR, Carvalho RM. Effect of irradiation mode and filling technique on resin/dentin bonding strength in class I cavities. Braz Oral Res 2004;18(3):260-5.

FIGURE 2 - Schematic representation of specimen preparation for microtensile bonding strength test. (A) Sectioned specimen of experimental groups; (B) sectioned specimens of control groups; (C) beam-shaped specimens; (D) micro-tensile bonding test.
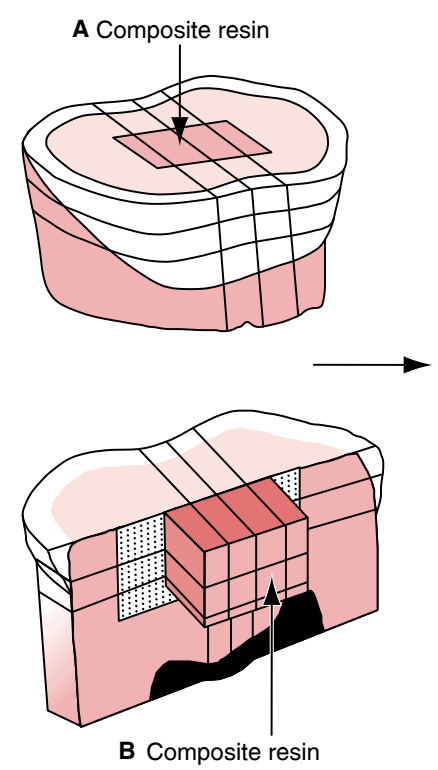

mentally placed in three-dimensional cavities and cured with the stepped light intensity mode were similar to that of controls groups, which were restored in flat surfaces $(p>0.05)$.

\section{DISCUSSION}

During the curing process, the time when the resin polymer develops a higher elastic modulus is called the gel point. Before this point and during the early phase of photo-polymerization, the polymer is in a flexible and fluid state. In the pregel phase, no tension is generated at the tooth/ composite interface, because the stress can be relieved by the composite flow. After the formation of a more rigid structure with higher modulus (gelpoint), the strain developed during further cure is transmitted to the bonded interface and adjacent tooth structures if contraction of the material is hindered by adhesion to the walls of three-dimensional cavities ${ }^{4,7,19}$.

Reduction of the shrinkage potential of composite resins by manufacturers and restorative techniques used by dentists are fundamental to avoid resin-based restorations with interfacial stress development, which compromises their longevity ${ }^{18}$. This study tested filling restorative techniques and irradiation modes to overcome the stress developed during the curing process of composite resins in class I cavities.

The soft-start or step-curing irradiation mode comprises the application of low-intensity light during initial phases of the curing process, followed by final cure with full intensity. This can provide time for the composite flow to occur, minimizing the shrinkage effects. Reduction in light intensity promotes reduction in the number of free radicals formed, lowering the overall rate of polymerization and allowing shrinkage strain in the polymer to be relieved by increased flow capability of the material $^{18}$. Afterwards, high light intensity is applied to complete the polymerization process and provide proper mechanical properties ${ }^{10,25}$.

Since the volumetric contraction of the composite can cause debonding forces and a part of this stress can be compensated during the initial phase of polymerization by the flow of the dental composite ${ }^{3,4}$, the extending in time of the pre-gel phase with stepped irradiation can preserve the marginal integrity of the restoration ${ }^{10,13,22,26}$ due to a reduction in the polymerization contraction stress $^{5,11,24}$.

The stepped irradiation mode used with incremental filling techniques to restore class I cavities provided bonding strength values similar to those of the control group. The initial low-intensity light may avoid the detrimental shrinkage effects on the 
Santos AJS, Giannini M, Paulillo LAMS, Lovadino JR, Carvalho RM. Effect of irradiation mode and filling technique on resin/dentin bonding strength in class I cavities. Braz Oral Res 2004;18(3):260-5.

TABLE 1 - Two-way analysis of variance.

\begin{tabular}{l|c|c|c|c|c}
\hline \hline \multicolumn{1}{c|}{ Source } & DF & Sum of squares & Mean square & F value & p $>$ F \\
\hline Filling technique & 2 & 511.63 & 255.81 & 13.70 & $0.0002^{*}$ \\
\hline Irradiation mode & 1 & 213.01 & 213.01 & 11.41 & $0.0034^{*}$ \\
\hline Interaction & 2 & 71.40 & 35.70 & 1.91 & 0.1766 \\
\hline \hline
\end{tabular}

*Statistical significance at the level of 5\%. DF: degrees of freedom.

TABLE 2 - Mean tensile bond strength values in MPa \pm standard deviations (N).

\begin{tabular}{l|c|c|c}
\hline \hline Filling technique & Continuous irradiation & & Stepped irradiation \\
\hline Control groups & $28.20 \pm 2.23(15)$ & $\mathrm{NS}$ & $29.10 \pm 1.55(16)$ \\
\hline Oblique & $16.95 \pm 3.41(15)^{*}$ & $\mathrm{~S}$ & $27.68 \pm 5.89(14)$ \\
\hline Horizontal & $20.50 \pm 3.27(15)^{*}$ & $\mathrm{~S}$ & $24.97 \pm 5.28(13)$ \\
\hline Bulk & $11.40 \pm 2.49(16)^{*}$ & $\mathrm{~S}$ & $14.08 \pm 4.57(16)^{*}$ \\
\hline
\end{tabular}

*Significant differences from control groups according to Dunnett's test ( $\mathrm{p}<0.05)$. NS - no statistical significant difference; $\mathrm{S}$ - significant difference (between irradiation modes). Means connected by vertical line are not significantly different according to Tukey's test $(\mathrm{p}>0.05)$. $\mathrm{N}$ : number of specimens.

bonded interface, producing bonding strength values similar to those obtained on flat surfaces and without cavity configuration influence. Both incremental methods provide higher bonding strength values than the bulk technique. However, when continuous irradiation was used, they did not match control group values.

Two factors may have contributed to the lower bonding strength values obtained with the bulk filling technique: increased polymerization contraction stress due to great volume of composite and decreased effectiveness of polymerization at

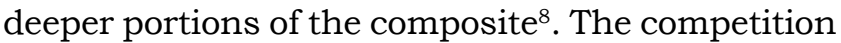
between the composite-dentin bonding strength and the polymerization contraction stress can be avoided, inserting composite resin in increments to reduce the volume of the resin and the stress generated on the cavity walls ${ }^{1,12,15,17}$.

In this study, the orientation of the dentinal tubules on the buccal wall was parallel to the bonded interface. Studies have shown that the bonding strength of the resin is not uniform inside a cavity, and the direction of the dentinal tubules appears to be an important variable regarding the formation of a hybrid layer in dentin ${ }^{16,21}$. The influence of tubule direction can result in higher bonding strength values for bonding performed with tubules oriented parallel to the surface ${ }^{14}$. The microtensile method allowed the measurement of bonding strength at small bonded areas and at a specific wall of a three-dimensional cavity ${ }^{20}$.
The class I cavity design was chosen because it resembles clinical situations with complex cavity preparation and restoration; and the results showed that the shrinkage potential of the composite and the cavity configuration factor affected the bonding strength. In flat surfaces, the large free surface allows resin to flow during the curing process, not compromising the bonding as observed in the control group ${ }^{27}$. Negative effects on the restoration-cavity interfaces promoted by forces of polymerization contraction can be controlled to some extent by using stepped irradiation and incremental filling restorative techniques in clinical restorations. Thus, the results lead us to reject the null hypothesis, because the irradiation mode and incremental filling techniques did affect the bonding strength to the dentin of the buccal wall of box-like class I cavities.

\section{CONCLUSIONS}

According to the methodology employed and based on the obtained results and on the statistical analysis, it can be concluded that:

1. Soft-start or step-curing irradiation mode applied following incremental techniques can improve bonding strength values of composite resin to buccal wall dentin of box-like class I cavities.

2. Bulk placement of composite resins is not recommended as a restorative procedure for dental cavities. 
Santos AJS, Giannini M, Paulillo LAMS, Lovadino JR, Carvalho RM. Effect of irradiation mode and filling technique on resin/dentin bonding strength in class I cavities. Braz Oral Res 2004;18(3):260-5.

\section{ACKNOWLEDGMENTS}

The authors are indebted to the Laboratory of Dental Materials (School of Dentistry of Piracicaba, State University of Campinas - FOP-UNICAMP)

\section{REFERENCES}

1. Ben-Amar AR, Liberman R, Nordenberg D, Metzger Z. The effect of retention grooves on gingival marginal leakage in class II posterior composite resin restorations. J Oral Rehabil 1988;15:325-31.

2. Carvalho RM, Pereira JC, Yoshiyama M, Pashley DH. A review of polymerization contraction: the influence of stress development versus stress relief. Oper Dent 1996;21:1724.

3. Davidson CL, de Gee AJ. Relaxation of polymerization contraction stress by flow in dental composites. J Dent Res 1984;63:146-8.

4. Davidson CL, de Gee AJ, Feilzer AJ. The competition between teeth composite-dentin bond strength and the polymerization contraction stress. J Dent Res 1984;63:13969.

5. Ernst CP, Kürschner R, Rippin G, Willershausen B. Stress reduction in resin-based composites cured with a two-step light-curing unit. Am J Dent 2000;13:69-72.

6. Feilzer AJ, de Gee AJ, Davidson CL. Setting stress in composite resin in relation to configuration of the restoration. J Dent Res 1987;66:1636-9.

7. Feilzer AJ, Dooren LH, de Gee AJ, Davidson CL. Influence of light intensity on polymerization shrinkage and integrity of restoration-cavity interface. Eur J Oral Sci 1995;103:3226.

8. Figueiredo Reis A, Giannini M, Ambrosano GM, Chan DC. The effects of filling techniques and a low-viscosity composite liner on bond strength to class II cavities. J Dent 2003;31:59-66.

9. Kanca J $3^{\text {rd }}$, Suh BI. Pulse activation: reducing resin-based composite contraction stresses at the enamel cavosurface margins. Am J Dent 1999;12:107-12.

10. Koran P, Kürschner R. Effect of sequential versus continuous irradiation of a light-cured resin composite on shrinkage, viscosity, adhesion and degree of polymerization. Am J Dent 1998;10:17-22.

11. Lim BS, Ferracane JL, Sakaguchi RL, Condon JR. Reduction of polymerization contraction stress for dental composites by two-step light-activation. Dent Mater 2002; 18:436-44.

12. Lutz E, Krejci I, Oldenburg TR. Elimination of polymerization stresses at the margins of posterior composite resin restorations: a new restorative technique. Quintessence Int 1986;17:777-84. for allowing the use of the Universal Testing Machine. This study was supported, in part, by grants 00/08347-0 and 01/02771-7 of The State of São Paulo Research Foundation (FAPESP).

13. Mehl A, Hickel R, Kunzelmann KH. Physical properties and gap formation of light-cured composites with and without softstart-polymerization. J Dent 1997;25:321-30.

14. Ogata M, Okuda M, Nakajima M, Pereira PNR, Sano $\mathrm{H}$, Tagami J. Influence of the direction of tubules on bond strength to dentin. Oper Dent 2001;26:27-35.

15. Opdam NJM, Feilzer AJ, Roeters JJM, Smale I. Class I occlusal composite resin restorations: in vivo post-operative sensitivity, wall adaptation, and microleakage. Am J Dent 1998;11:229-34.

16. Phrukkanon S, Burrow MF, Tyas MJ. The effect of dentine location and tubule orientation on the bond strengths between resin and dentine. J Dent 1999;27:265-74.

17. Pollack BF. Class II composites: 1987 thoughts and techniques. NY State Dent J 1987;53:25-7.

18. Rueggeberg F. Contemporary issues in photocuring. Compend Contin Educ Dent 1999;Suppl:4-15.

19. Sakaguchi RL, Berge HX. Reduced light energy density decreases post-gel contraction while maintaining degree of conversion in composites. J Dent 1998;26:695-700.

20. Sano H, Shono T, Sonoda H, Takatsu T, Ciucchi B, Carvalho $\mathrm{R}$, et al. Relationship between surface area for adhesion and tensile bond strength - evaluation of a microtensile bond test. Dent Mater 1994;10:236-40.

21. Schüpbach P, Krejci I, Lutz F. Dentin bonding: effect of tubule orientation on hybrid-layer formation. Eur J Oral Sci 1997; 105:344-52.

22. Uno S, Asmussen E. Marginal adaptation of a restorative resin polymerized at reduced rate. Scand J Dent Res 1991;99:440-4.

23. van Dijken JW, Horstedt P, Waern R. Directed polymerization shrinkage versus a horizontal incremental filling technique: interfacial adaptation in vivo in class II cavities. Am J Dent 1998;11:165-72.

24. Watts DC, al Hindi A. Intrinsic soft-start polymerization shrinkage-kinetics in an acrylate-based resin-composite. Dent Mater 1999;15:39-45.

25. Yap AUJ, Ng SC, Siow KS. Soft-start polymerization: influence on effectiveness of cure and post-gel shrinkage. Oper Dent 2001;26:260-6.

26. Yoshikawa T, Burrow MF, Tagami J. A light curing method for improving marginal sealing and cavity wall adaptation of resin composite restorations. Dent Mater 2001;17:359-66.

27. Yoshikawa T, Sano H, Burrow MF, Tagami J, Pashley DH. Effect of dentin depth and cavity configuration on bond strength. J Dent Res 1999;78:898-905. 